\title{
Local Taxes Efficiency in the Context of Regional Socio-Economic Development
}

\author{
YarYNa V. SAMUSEVYchi, YULIIA O. SERGIENKo ${ }^{i i}$, Bhola KHAN ${ }^{i i i}$
}

\begin{abstract}
Development of regions is one of the priority areas of state regional policy, which purpose is to create appropriate conditions for dynamic, balanced socio-economic development of Ukraine and regions, improving living standards, ensuring compliance with state-guaranteed social protection for each citizen and elimination of main regional imbalances. Ensuring competitiveness and socio-economic development of regions is a prerequisite for growth in the local and national economies. The impact of increasing the financial autonomy of local governments primarily depends on their financial provision. One of the primary sources of local revenues is local taxes and fees, which enhance the efficiency of using budget instruments for the socio-economic development of administrative units. The main contribution of the research lies in the testing of the hypothesis of existing relationship processes between local taxes and indicators of regional development based on panel data analysis for all regions of Ukraine using the regression model in Stata SE and MS Excel. The research period covers 20182020. The dataset includes parameters of local tax revenues and indicators of regional development. To substantiate the role of local taxes in regional development, a set of hypotheses about the relationships between local tax revenues and regional development dynamics were specified. In the process of calculations, 18 regression equations (ordinary least squares panel regression method) were created, which allow estimating the impact of local taxes on the general indicators of regional development. Calculations results proved that local taxes have a significant positive effect on ensuring the growth in regional social and economic development indicators. This creates a background for enhancing the financial capacity of local budgets due to the improvements in the local tax system.
\end{abstract}

Keywords: local taxes, development of regions, local budgets, regulatory efficiency of local taxes, panel data analysis.

Introduction. One of the main conditions for the successful development of regions is an effective and efficient local self-governance system. The democratic principles of the development of modern society require the complete functioning of the Institute of local taxation. To ensure the performance of their functions, create a proper living environment for the community, local governments must have sufficient financial resources, which are based on local budgets. One of the essential sources of income of local authorities is local taxes and fees. Increasing the role of local taxes and their share in own revenues of local budgets is the primary condition for the socio-economic development of regions.

Problem statement. The economic meaning of the term "local taxes", the sources of their formation, the main tools for increasing their filling and efficient use have been widely considered in the modern economical literature of domestic and foreign scholars.

\footnotetext{
${ }^{i}$ Yaryna V. Samusevych, C.Sc. (Economics), Department of Accounting and Taxation, Sumy State University;

${ }^{i i}$ Yuliia O. Sergienko, student of Academic and Research Institute of Business, Economics and Management, Sumy State University;

${ }^{i i i}$ Bhola Khan, C.Sc. (Economics), Head of the Department of Economics, Yobe State University, Damaturu, Nigeria.

(C) Ya. V. Samusevych, Yu. O. Sergienko, B. Khan, 2021.

https://doi.org/10.21272/mer.2021.92.07
} 
Local taxation's fiscal and regulatory efficiency has been given more attention as one of the essential components contributing to territorial communities' absolute self-sufficiency and sustainability. This aspect is strengthened by the growing trends of decentralization in the formation of financial resources.

The purpose of the research is to analyze local taxes' fiscal efficiency and investigate the relationship between them and indicators of regional development.

Results of the research. The regional tax potential is formed and developed as a result of the functioning of spheres, sectors and segments of socio-economic systems of the region, constituting a part of the aggregate concentration of financial resources of the territorial community for their further use to ensure efficient social and economic development of the regional economy.

It should be noted that local taxation plays a vital role in the implementation and growth of the economic potential of cities, which, in turn, creates more opportunities for improving the welfare of the population as a whole.

Thus, local taxes are drivers of the economic and social development of the cities. Significant capital investments are necessary to satisfy the basic needs of the urban population [4].

For example, the economic growth of cities is possible due to the development strategy, which is aimed at improving the level of urban infrastructure, namely the quality of roads, communications, the housing sector, the sphere of services and entertainment, the availability of qualified personnel, sufficient number of jobs. All of this is the potential for the development of cities, which, in turn, contributes to raising the level of the economy of the country and increasing the social well-being of the population [7].

Besides this, local taxes must be directed to help the unprotected groups of the population. Nowadays, the importance of the social function of taxes is increasing, so providing benefits and material assistance is necessary to support the people who require it [2].

Modern political and economic transformations in Ukraine are aimed at the restoration of democratic freedoms. Recently, local governments are being reformed with a focus on ensuring these rights. The effectiveness of local governments has a significant and operational impact on public relations, especially the growth welfare of the population living on the relevant territory, which is the primary purpose of local government [3].

Local self-government acts as a specific form of realization of public authority. Thus, the main task and purpose of local government are to satisfy local needs and solve specific problems that appear in a particular territory by their efforts.

It's necessary to define the authority of local governments to select indicators of the socioeconomic development of regions.

The most important of them are:

- $\quad$ formation and implementation of the local budget;

- $\quad$ current and strategic planning of the functioning and development of the territorial community;

- approve programs of socio-economic and cultural development and monitor their implementation;

- providing high-quality functioning of engineering infrastructure (roads, transport, etc.), public order, appropriate environmental and sanitary condition of the territory;

- $\quad$ solution of social problems (housing, education, culture) and providing social protection;

- $\quad$ organization of cultural and artistic programs of local significance [1]. 
Я. В. Самусевич, Ю. О. Сергієнко, Б. Кхан.

Ефективність місцевих податків в контексті соціально-економічного розвитку регіонів

Thus, the appointed functions are common to all spheres of local life and are focused on solving the issues of the local population.

An essential step in our research is to determine the impact of tax revenues of local taxes, namely: single tax, flat tax, land tax, and transport tax with indicators of regional development. We conduct the study using panel regression analysis (generalized least squares model with random effects).

For this analysis, we need to choose the factor and the resultant signs. Local taxes, in this case, are the factor indicators.

The world practice shows that the primary condition for regional development is the practical cooperation between local governments, ensuring the transformation of resources from stock to flow.

Regarding the resultant indicators of regional development, they were selected by the responsibilities of local tax authorities and their expenditures by the current legislation, especially:

- $\quad$ level of coverage of social services for persons in difficult life circumstances;

- unemployment rate;

- $\quad$ expenditures on environmental protection;

- capital investment in construction;

- capital investment in transport;

- capital investments in health care and social assistance;

- capital investments in art, sports, entertainment and recreation.

The impact of each taxon on the relevant development indicators is based on its probability. The study was conducted for the period 2018-2020. Let's consider the importance of each of the selected indicators for the socio-economic development of regions.

It should be noted that the data for the analysis were taken in the context of all Ukrainian regions. In the process of calculations, there were created 18 regression equations, which allow estimating the impact of local taxes on the general indicators of regional development. We need to consider the importance of each of the indicators and their possible relationship with local taxes.

Capital construction is one of the most critical sectors of the national economy, which is a mechanism for implementing the strategic objectives of economic development. Moreover, each region wants to create comfortable public services in the main spheres: education, health care, sports, security, administrative services. Therefore, the constant growth of capital investments in construction and their effective use guarantee success in improving the quality of life of the population.

Also, one of the leading indicators of economic development of the regions is capital investment in transport. Today, urban and intercity transport has few technical problems, particularly the condition of vehicles and the deterioration of seating. Also, there is a problematic transport situation at present in large cities, the main reason for this is the increase in the number of cars with an underdeveloped street and road network. Therefore, technical and technological modernization of transport is a priority for states and regions.

Health care is a component of social services, which plays a crucial role in ensuring the well-being of the population because health is the primary indicator of the quality of life. Capital investments in health care and social assistance are caused by the need to provide for social needs but significant economic dividends also return them in the form of growth of the country's national income. 
Yaryna V. Samusevych, Yuliia O. Sergienko, Bhola Khan.

Local Taxes Efficiency in the Context of Regional Socio-Economic Development

Thus, investments in health care should be regarded as a contribution to the development of the national economy and the increase in public well-being. The growth of health care financing due to the rise in the total amount of expenditures on the social sphere over the past decades has become a noticeable trend in the dynamics of economic processes in developed countries.

Modern life is unthinkable without social protection. Social protection measures support the realization of the human right to social security and economic and social needs. Welldesigned social protection systems contribute to the reduction of poverty and inequality while maintaining social unity and stability. Without extending social protection to those who have previously been deprived of it, it's impossible to reduce the insecurity and vulnerability of various social groups.

The problem of unemployment is extremely urgent today. If the available resources of the labor force are not fully used, then the economic system works without reaching the maximum of its production capabilities. Therefore, employment reveals one of the most critical aspects of human social development, related to the satisfaction of his needs in the sphere of labor.

The financial provision of the natural environment is also a relevant problem. Signs of deterioration of environmental conditions in our country are becoming more and more noticeable: pollution of atmospheric air, surface and underground water, deterioration of the quality of food products. Therefore, among the main priorities of regional social and economic development policy is the formation of a new mechanism of social development, including locations for physical activities, arts, and places for entertainment.

Let's analyze the impact of local taxes on regional development indicators in Ukraine (Table 1).

Table 1

Results of regression analysis of the impact of local taxes on indicators of regional development in the regions of Ukraine for 2018-2020

\begin{tabular}{|c|c|c|c|c|c|c|c|c|}
\hline $\begin{array}{l}\text { Resulting } \\
\text { variable }\end{array}$ & $\begin{array}{c}\text { Coefficient } \\
\text { of } \\
\text { influence }\end{array}$ & $\begin{array}{l}\text { Standard } \\
\text { Error }\end{array}$ & $\begin{array}{c}\mathrm{t}- \\
\text { value }\end{array}$ & $\begin{array}{c}\mathrm{p}- \\
\text { value }\end{array}$ & {$[95 \%$ Conf } & Interval] & Sign & $\begin{array}{c}\text { Mean } \\
\text { dependent } \\
\text { var } \\
\end{array}$ \\
\hline $\begin{array}{c}\text { Level of } \\
\text { coverage of } \\
\text { social services, } \\
\% \\
\end{array}$ & -12941.447 & 32615.976 & -0.40 & 0.692 & -76867.586 & 50984.691 & & 2342603.899 \\
\hline $\begin{array}{l}\text { Unemployment } \\
\text { rate, \% }\end{array}$ & -65579.784 & 84390.555 & -0.78 & 0.437 & -230982.23 & 99822.666 & & 2452167.529 \\
\hline $\begin{array}{l}\text { Expenditures } \\
\text { on } \\
\text { environmental } \\
\text { protection, } \\
\text { thousands UAN }\end{array}$ & 0.346 & 0.072 & 4.84 & 0 & 0.206 & 0.486 & $* * *$ & 2342603.899 \\
\hline $\begin{array}{c}\text { Capital } \\
\text { investment in } \\
\text { construction, } \\
\text { thousands UAN }\end{array}$ & -0.129 & 0.064 & -2.02 & 0.043 & -0.254 & -0.004 & $* *$ & 2452167.529 \\
\hline
\end{tabular}


Я. В. Самусевич, Ю. О. Сергієнко, Б. Кхан.

Ефективність місцевих податків в контексті соціально-економічного розвитку регіонів

Table 1(continued)

\begin{tabular}{|c|c|c|c|c|c|c|c|}
\hline $\begin{array}{c}\text { Capital } \\
\text { investment in } \\
\text { transport, } \\
\text { thousands } \\
\text { UAN }\end{array}$ & -0.025 & 0.138 & -0.18 & 0.855 & -0.296 & 0.245 & 2452167.529 \\
\hline $\begin{array}{c}\text { Capital } \\
\text { investments in } \\
\text { health care and } \\
\text { social } \\
\text { assistance, } \\
\text { thousands } \\
\text { UAN }\end{array}$ & -0.396 & 0.625 & -0.63 & 0.527 & -1.622 & 0.83 & 2452167.529 \\
\hline $\begin{array}{c}\text { Capital } \\
\text { investments in } \\
\text { art, sports, } \\
\text { entertainment } \\
\text { and recreation, } \\
\text { thousands } \\
\text { UAN }\end{array}$ & 0.786 & 1.455 & 0.54 & 0.589 & -2.066 & 3.638 & 2491802.794 \\
\hline
\end{tabular}

According to Table 1, we can conclude that there is a relationship between tax revenues and two indicators, namely expenditures on environmental protection and capital investment in construction. The impact of local taxes on expenditures on environmental protection is strength, with an average approximation error of only $0.072 \%$. Obtained results confirm, that changes in the local tax revenues by 1 thousand UAH are related to changes in the analyzed indicator on average by $2342603.89 \mathrm{UAH}$.

Also, the relationship between local taxes and investments is established, but this influence is less intense. Thus, the increase in tax revenues with a regional average of 1 thousand UAH leads to increased capital investment in construction on average by $2452167.529 \mathrm{UAH}$.

Analyzing the effect of the local taxes on other regional development indicators in the regions of Ukraine statistical significance of the equation is not confirmed (according to the values of R-squared, Chi-square parameters). It is established that in the studied situation, the general variability of investments in building materials does not appear at all by the change of receipts from the local tax revenues.

Now it's necessary to analyze the elements of local taxes according to their possible correlation with the indicators of regional development. First, let's examine the impact of a flat tax on capital investment in construction in the regions of Ukraine for 2018-2020 (Table 2).

It should be noted that natural or legal persons pay the flat tax for exceeding the amount of residential or non-residential property beyond the legal limit. Flat taxes, having a definite value, allow the government to generate more certain and predictable income than taxation of transactions, profits, or income.

Thus, the statistical significance of the equation is not confirmed (according to the values of R-squared, Chi-square parameters). Nevertheless, it is established that in the studied situation, the general variability of investments in building materials does not appear at all by the change of receipts from the flat tax. 
Yaryna V. Samusevych, Yuliia O. Sergienko, Bhola Khan. Local Taxes Efficiency in the Context of Regional Socio-Economic Development

Table 2

Results of regression analysis of the impact of a flat tax on investment in construction in the regions of Ukraine for 2018-2020

\begin{tabular}{|c|c|c|c|c|c|c|c|}
\hline Result variables & $\begin{array}{c}\text { Coefficient } \\
\text { of influence }\end{array}$ & $\begin{array}{c}\text { Standard } \\
\text { error }\end{array}$ & t-value & p-value & [95\% Conf & Interval] & Sig \\
\hline $\begin{array}{c}\text { Capital investment } \\
\text { in construction, } \\
\text { thousands UAN }\end{array}$ & -0.004 & 0.006 & -0.71 & 0.478 & -0.017 & 0.008 \\
\hline Constant & 164772.6 & 26180.206 & 6.29 & 0 & 113460.33 & 216084.86 & $* * *$ \\
\hline \multicolumn{7}{|c|}{ Model adequacy parameters } \\
\hline Mean dependent var & 156766.906 & \multicolumn{2}{|c|}{ SD dependent var } & 126695.938 \\
\hline Overall r-squared & 0.364 & \multicolumn{2}{|c|}{ Number of obs } & 66.000 \\
\hline Chi-square & 0.504 & \multicolumn{2}{c|}{ Prob > chi2 } & 0.478 \\
\hline R-squared within & 0.225 & R-squared between & 0.490 \\
\hline
\end{tabular}

Note: $* * * p<0.01, * * p<0.05, * p<0.1$. Authors' calculations based on $[5,6,8]$

The next step is to analyze the impact of transport tax on capital investment in transport in the regions of Ukraine for 2018-2020 (Table 3).

Transport tax is an analog of the wealth tax, which is paid to local budgets. The amount of transport tax depends on the value of the car and its age. For example, if the car's value exceeds 2.25 million UAN, the buyer will have to pay an additional 25 thousand UAH of transport tax each year until the car doesn't turn five years.

According to Table 3, we can conclude that the relationship between the transport tax and investment in transport is strong, with an average approximation error of $13.076 \%$. Obtained results confirm that the increase in tax revenues by 1 thousand UAH leads to increased capital investment in transport on average by $725591.5 \mathrm{UAH}$.

Table 3

Results of regression analysis of the impact of transport tax on investment in transport in the regions of Ukraine for 2018-2020

\begin{tabular}{|c|c|c|c|c|c|c|c|}
\hline Result variables & $\begin{array}{l}\text { Coefficient } \\
\text { of influence }\end{array}$ & $\begin{array}{c}\text { Standard } \\
\text { error }\end{array}$ & t-value & p-value & [95\% Conf & Interval] & Sig \\
\hline $\begin{array}{c}\text { Capital } \\
\text { investment in } \\
\text { transport, } \\
\text { thousands UAN }\end{array}$ & 94.189 & 13.076 & 7.20 & 0 & 68.561 & 119.818 & $* * *$ \\
\hline Constant & -24616.084 & 159764.12 & -0.15 & .878 & -337748.01 & 288515.85 & \\
\hline \multicolumn{8}{|c|}{ Model adequacy parameters } \\
\hline \multicolumn{2}{|c|}{ Mean dependent var } & 725591.485 & \multicolumn{3}{|c|}{ SD dependent var } & \multicolumn{2}{|l|}{936560.368} \\
\hline Overall r-squared & & 0.553 & \multicolumn{3}{|c|}{ Number of obs } & \multicolumn{2}{|l|}{66.000} \\
\hline Chi-square & & 51.885 & \multicolumn{2}{|c|}{ Prob $>$ chi 2} & & \multicolumn{2}{|l|}{0.000} \\
\hline R-squared within & & 0.343 & \multicolumn{2}{|c|}{ R-squared between } & & 0.593 & \\
\hline
\end{tabular}


Я. В. Самусевич, Ю. О. Сергієнко, Б. Кхан.

Ефективність місцевих податків в контексті соціально-економічного розвитку регіонів

The impact of land tax on investment in contribution, health care, and social assistance in the regions of Ukraine is shown in Table 4. It should be noted that this is a mandatory payment that is collected from the owners of land plots and landowners.

Table 4

Quality indicators of the regression equation of land tax on investment in contribution, health care, and social assistance in the regions of Ukraine for 2018-2020

\begin{tabular}{|c|c|c|c|c|c|c|c|c|}
\hline Resulting variable & $\begin{array}{c}\text { Coefficient } \\
\text { of influence }\end{array}$ & $\begin{array}{c}\text { Standard } \\
\text { Error }\end{array}$ & $\begin{array}{c}\mathrm{t}- \\
\text { value }\end{array}$ & $\begin{array}{c}\mathrm{p}- \\
\text { value }\end{array}$ & $\begin{array}{c}{[95 \%} \\
\text { Conf }\end{array}$ & Interval] & Sig & $\begin{array}{c}\text { Mean } \\
\text { dependent var }\end{array}$ \\
\hline $\begin{array}{c}\text { Capital investment } \\
\text { in construction, } \\
\text { thousands UAN }\end{array}$ & -0.073 & 0.032 & -2.28 & 0.022 & -0.135 & -0.01 & $* *$ & 1093284.134 \\
\hline $\begin{array}{c}\text { Capital } \\
\text { investments in } \\
\text { health care and } \\
\text { social assistance, } \\
\text { thousands UAN }\end{array}$ & -0.343 & 0.294 & -1.17 & 0.244 & -0.919 & 0.234 & 681531.27 \\
\hline
\end{tabular}

Note: $* * * p<0.01, * * p<0.05, * p<0.1$. Authors' calculations based on $[5,6,8]$

According to Table 4, we can conclude that the relationship between the land tax and investment in construction is strong, with an average approximation error of only $0.032 \%$. Thus, obtained results confirm that the increase in tax revenues with a regional average of 1 thousand UAH leads to increased capital investment in construction on average by 1093284.134 UAH.

Analyzing the effect of the land tax on investment in health care and social assistance in the regions of Ukraine statistical significance of the equation is not confirmed (according to the values of R-squared, Chi-square parameters). Nevertheless, it is established that in the studied situation, the general variability of investments in building materials does not appear at all by the change of receipts from the land tax.

Let's analyze the impact of a single tax on investment on regional development indicators in the regions of Ukraine (Table 5). It's one of the most progressive and fundamental local taxes.

The key concept that should be paid attention to when considering the single tax is simplifying the taxation system. Thus, its main feature is that it relieves taxpayers from paying other taxes and fees, especially income tax, personal income tax, value-added tax, land tax, and rent tax.

Table 5

Quality indicators of the regression equation of the impact of a single taxon indicators of regional development in Ukraine for 2018-2020

\begin{tabular}{|c|c|c|c|c|c|c|c|c|}
\hline $\begin{array}{c}\text { Resulting } \\
\text { variable }\end{array}$ & $\begin{array}{c}\text { Coefficient } \\
\text { of } \\
\text { influence }\end{array}$ & $\begin{array}{c}\text { Standard } \\
\text { Error }\end{array}$ & $\begin{array}{c}\mathrm{t}- \\
\text { value }\end{array}$ & $\begin{array}{c}\mathrm{p}- \\
\text { value }\end{array}$ & {$[95 \%$ Conf } & Interval] & Sign & $\begin{array}{c}\text { Mean } \\
\text { dependent var }\end{array}$ \\
\hline $\begin{array}{c}\text { Level of } \\
\text { coverage of } \\
\text { social services }\end{array}$ & -16628.193 & 13276.171 & -1.25 & 0.21 & - & 92649.011 & 9392.624 & 1133281.089 \\
\hline $\begin{array}{c}\text { Unemployment } \\
\text { rate }\end{array}$ & -35454.312 & 39468.856 & -0.90 & 0.369 & $\begin{array}{c}- \\
112811.85\end{array}$ & 41903.225 & & 1194151.607 \\
\hline
\end{tabular}


Yaryna V. Samusevych, Yuliia O. Sergienko, Bhola Khan. Local Taxes Efficiency in the Context of Regional Socio-Economic Development

Table 5 (continued)

\begin{tabular}{|c|c|c|c|c|c|c|c|c|}
\hline $\begin{array}{l}\text { Expenditures } \\
\text { on } \\
\text { environmental } \\
\text { protection }\end{array}$ & 0.129 & 0.03 & 4.33 & 0 & 0.071 & 0.188 & $* * *$ & 1133281.089 \\
\hline $\begin{array}{c}\text { Capital } \\
\text { investment in } \\
\text { construction }\end{array}$ & -0.036 & 0.031 & -1.17 & 0.243 & -0.097 & 0.025 & & 1194151.607 \\
\hline $\begin{array}{c}\text { Capital } \\
\text { investment in } \\
\text { transport }\end{array}$ & -0.065 & 0.061 & -1.07 & 0.283 & -0.184 & 0.054 & & 1194151.607 \\
\hline $\begin{array}{c}\text { Capital } \\
\text { investments in } \\
\text { health care and } \\
\text { social } \\
\text { assistance }\end{array}$ & 0.146 & 0.321 & 0.46 & 0.649 & -0.483 & 0.775 & & 1194151.607 \\
\hline $\begin{array}{c}\text { Capital } \\
\text { investments in } \\
\text { art, sports, } \\
\text { entertainment } \\
\text { and recreation }\end{array}$ & 0.331 & 0.704 & 0.47 & 0.639 & -1.05 & 1.711 & & 1209942.622 \\
\hline
\end{tabular}

According to Table 5, we can conclude a relationship between local tax revenues and expenditures on environmental protection. The impact of local taxes on these indicators is strong, with an average approximation error of only $0.03 \%$. Obtained results confirm that an increase in tax revenues with a regional average of 1 thousand UAH leads to an increase in the standard of 1133281.089 UAH.

Analyzing the effect of the single tax on other regional development indicators in the regions of Ukraine statistical significance of the equation is not confirmed. It is established that in the studied situation, the general variability of regional indicators doesn't appear at all by the change of receipts from the local tax revenues.

Conclusions. Existing relationship processes between local taxes and indicators of regional development based on panel data analysis for all regions of Ukraine using the regression model in Stata SE and MS Excel is conducted. In the process of calculations, the regression equations were created, which allow estimating the impact of local taxes on the general indicators of regional development. According to the results of the calculations, the following conclusions can be made: there is a direct correlation between local taxes and two indicators, namely expenditures on environmental protection and capital investment in construction; transport and land taxes have a direct impact on capital investments in construction; there is a relationship between local tax revenues and expenditures on environmental protection.

\section{References}

1. Budget Code of Ukraine. Retrieved from: https://zakon.rada.gov.ua/laws/show/2456-17\#Text

2. Grynchyshyn, I. M. (2018). Napriamy pidvyshcshennia efectyvnosti vykorystannia biudgetnyh koshtiv na sotsialnyi zahyst v Ukraini: regionalnyi ta mistsevyi vymiry [Directions of increasing the efficiency of budgetary expenditures for social security in Ukraine: regional and local context]. Regionalna Economica, 4, 94-102. Retrieved from: http://nbuv.gov.ua/UJRN/regek_2018_4_12

3. Kubai, T. Ye. (2015). Mistseve samovryadvannya yak instytut demokratychnogo suspilstva: upravlinsko-pravovyi aspect [Local government as the Institute of democratic society: administrative 
Я. В. Самусевич, Ю. О. Сергієнко, Б. Кхан.

Ефективність місцевих податків в контексті соціально-економічного розвитку регіонів

and legal aspect]. Efectyvnist derzhavnoho upravlinnia, 42, 266-273. Retrieved from: http://nbuv.gov.ua/UJRN/efdu_2015_42_32

4. Martyniuk, I. \& Bohatyrova, Y. (2019). Mistseve opodatkuvannia v Ukraini: suchasnyi stan ta perspectyvy rozvytku [Local taxation in Ukraine: current state and development prospects]. Ekonomika ta derzhava, 6, 27-31.

5. Ministry of Development of Communities and Territories of Ukraine. Retrieved from: https://www.minregion.gov.ua

6. Open Budget. Retrieved from: https://openbudget.gov.ua

7. Prots, N. V. (2016). Sutnist ta fiskalna rol mistsevyh podatkiv ta zboriv v umovah reformuvannia biudzhetnoho ta podatkovoho zakonodavstva [The essence and fiscal role of local taxes and fees in the context of reforming fiscal and tax legislation]. Global and national problems of the economy, 13, 536-541. Retrieved from: http://global-national.in.ua/archive/13-2016/108.pdf

8. State Statistics Service of Ukraine. Retrieved from: http://www.ukrstat.gov.ua

Manuscript received 09 March 2021

\author{
Mechanism of Economic Regulation, 2021, No 2, 66-75 \\ ISSN 1726-8699 (print)
}

Ефективність місцевих податків в контексті соціально економічного розвитку регіонів

\title{
ЯРИНА ВАЛЕНТИНІвНА САМУСЕВИЧ*, ЮЛІЯ ОЛЕГІВНА СЕРГІєНКО ${ }^{* *}$, БХОЛА КХАН ${ }^{* * *}$
}

* кандидат економічних наук, викладач кафедри бухгалтерського обліку і оподаткування

Сумського державного університету,

вул. Р.-Корсакова, 2, Суми, 40007, Україна, тел.:00-380-66-1346081, e-mail:y.samusevych@uabs.sumdu.edu.иa

** студент Навчально-наукового інституту бізнесу, економіки та менеджменту

Сумського державного університету,

вул. Р.-Корсакова, 2, Суми, 40007, Украӥна, тел.:00-380-66-8520475, e-mail: yuliasergienko1557@gmail.com

*** кандидат економічних наук, завідувач кафедри економіки, Державний університет Йобе,

шлях Сер Кашим Ібрагім, КМ 7, Даматуру, Р.М.В. 1144, Нігерія,

тел.: +2348084028462, e-mail: bholakhan.apj@gmail.com

Розвиток регіонів є одним із пріоритетних напрямків державної регіональної політики, метою якого $\epsilon$ створення належних умов для динамічного, збалансованого соціально-економічного розвитку України та регіонів, підвищення рівня життя, забезпечення дотримання гарантованого державою соціального захисту кожного громадянина та усунення основних регіональних диспропорцій. Вплив збільшення фінансової автономії органів місцевого самоврядування в першу чергу залежить від їх фінансового забезпечення. Одним з основних джерел місцевих доходів $\epsilon$ місцеві податки та збори, що підвищують ефективність використання бюджетних інструментів для соціально-економічного розвитку адміністративних одиниць. Основний внесок дослідження полягає у тестуванні гіпотези існуючих процесів взаємозв'язку між місцевими податками та показниками регіонального розвитку на основі панельного аналізу даних для всіх регіонів України з використанням регресійної моделі в Stata SE та MS Excel. Період дослідження включає 2018-2020 pр. Вибірка даних включає показники надходження місцевих податків, а також індикатори регіонального розвитку. Для обгрунтування ролі місцевих податків у регіональному 
Yaryna V. Samusevych, Yuliia O. Sergienko, Bhola Khan. Local Taxes Efficiency in the Context of Regional Socio-Economic Development

розвитку було визначено ряд гіпотез щодо взаємозв'язків між надходженнями місцевих податків та динамікою регіонального розвитку. В процесі розрахунків було створено 18 рівнянь регресії (панельна регресія за методом найменших квадратів), які дозволяють оцінити вплив місцевих податків на загальні показники регіонального розвитку. Розрахунки засвідчили, що місцеві податки мають статистично значимий позитивний вплив на забезпечення зростання індикаторів регіонального соціального та економічного розвитку. Це створює підгрунтя для посилення фінансової спроможності місцевих бюджетів у результаті вдосконалення системи місцевих податків.

Ключові слова: місцеві податки, розвиток регіонів, місцеві бюджети, регулятивна функція місцевих податків, панельний аналіз даних.

JEL Codes: H20, H71, R11

Table: 5; References: 8

Language of the article: English 